Cite this: Indo. Chim. Acta., 2020, 13, 1.

Received Date: 4th March 2020 Accepted Date: 24th June 2020

Keywords:

QSAR;

caffeic acid;

phenethylamino

DOI:

http://dx.doi.org/10.20956/ica.v1 3i1.9565

\title{
Synthesis of a Cinnamic Acid Derivative and Bioactivity as an Anticancer Based on Result Quantitative Structure Activity Relationship (QSAR) Analysis
}

\begin{abstract}
Abdul Fattah ${ }^{1 *}$, Firdaus ${ }^{1}$, Nunuk Hariani Soekamto ${ }^{1}$
Abstract. Synthesis of compound (E)-4-(3-oxo-3-(phenethylamino)prop-1-en-1-il)1,2-phenylene diacetate (3) analogue from (E)-3-(3,4-dihydroxyphenyl)-Nphenethylacrylamide as recommendation of analysis result of QSAR was done. In this synthesis, we used caffeic acid and it was used as starting material through reaction of acetylation, chlorination, and amidation. Acetylation was carried out by using acetic anhydride in pyridine at room temperature for 4 hours. Chlorination by using thionyl chloride reagent in dimethylphormamide in conditions of $80^{\circ} \mathrm{C}$ for 4 hours, and continued with amidation using phenethylamine in dichloromethane solvent at room temperature for 1 hour. The structure of each reaction product phase was identified by using FT-IR spectrophotometer. The amidation phase also identified by using $1 \mathrm{H}$ NMR, 13C-NMR, HSQC and HMBC. Acetylation produces white crystalline solids with melting point $182-1840 \mathrm{C}$, and amidation produces compound 3 such us white crystalline with melting point $170-1730 \mathrm{C}$. The results of bioactivity test on murine leukaemia P-388 cells showed that the bioactivity of compound 3 was clarified the strongest (IC50 $=0,5 \mu \mathrm{g} / \mathrm{mL}$ ) so it was very potentially used as anticancer drug.
\end{abstract}

\section{Introduction}

(E)-3-(4-hydroxyphenyl)acrylate acid and its derivatives are known to have the ability to reduce chronic disease (Nakamura et al., 2014). The compounds in this group show biological activities such as antioxidants, hepaprotective, antidiabetic, antimicrobial, and so on (Sharma, 2011). Research conducted by Peng et al., (2015) found that esters derived from (E)-3-(4-hydroxyphenyl)acrylate acid were able to inhibit A-549 lung cancer cells. The results of Firdaus et al. (2012) also showed that secondary and tertiary amide p-cumaric acid derivatives showed activity against murine leukaemia P-388 cells. Similarly, anilide derivatives of (E)-3-(3,4-dihydroxy phenyl)acrylate acid are powerful antioxidants with IC50 of $0.3 \mu \mathrm{M}$ (Rajan et al., 2001). Specifically for amides from cinnamic acid compounds, the results of the comparison of bioactivity against 1,1-diphenyl-2-picrylhydrozyl (DPPH)

${ }^{1}$ Department of Chemistry, Faculty of Mathematics and Natural Science, University of Hasanuddin, Indonesia; Email: abdfattah046@gmail.com the amide from (E)-3-(4-hydroxy-3,5dimethoxyphenyl)acrylate acid has the highest bioactivity (Stankova et al., 2009).

Derivatives of (E)-3-(3, 4-dihydroxyphenyl) acrylate acid also show interesting bioactivity. Most acid anilides (E)-3(3,4-dihydroxyphenyl)acrylate acid synthesized show antioxidant activity (Hung et al., 2005). Phenethyl esters (E)3-(3,4-dihydroxyphenyl) acrylates acid, as one of the natural active ingredients of propolis, show unique biological activities such as anti-tumour, antioxidant, antiinflammatory, immune regulation, and beneficial properties for treatment (Cho et al., 2014; Zhang et al., 2014).

(E)-3-(3,4-dihydroxyphenyl)acrylate acid as an anticancer potential has the potential to be developed, but on the other hand, the synthesis process does not necessarily produce compounds with the expected bioactivity. This is a challenge for researchers to build in strategies in obtaining new active compounds. One plan that has been developed in the design of new compounds is computational chemistry (Pranowo, 2003). 
The design of new compounds is usually done by using the Quantitative Structure-Activity Relationship (QSAR) method. The QSAR methodology is used to systematically analyze the properties that accompany chemical structures of compounds in relation to available biological data (Simon-Hettich et al., 2006; Tropsha and Golbraikh, 2007).

The results of the preliminary analysis using QSAR in this study stated that the current position of the compound (E)3-(3,4-dihydroxyphenyl)acrylate acid was at position numbers 5, 6, and 10 as shown in Figure 1. Addition of electron withdrawal groups or the electron-pushing group at this position allows the bioactivity of compounds to increase or decrease. Therefore, it is necessary to conduct research by synthesizing several compounds containing groups whose induction and mesomeric properties differ in that position.

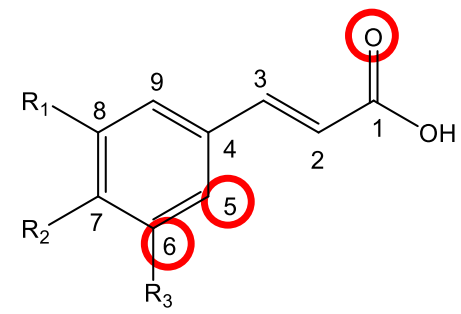

Figure 1. Numbering structure of cinnamic acid parent compounds.

Based on the results of the QSAR analysis, the research was chosen to synthesize the target compound, namely (E)4-(3-oxo-3-(phenethylamino)prop-1-en-1-yl)-1,2 phenylene diacetate (3), as shown in Figure 2. Inside compound 3, there is an acetyl group as the withdrawal group at position 6 and 7 .

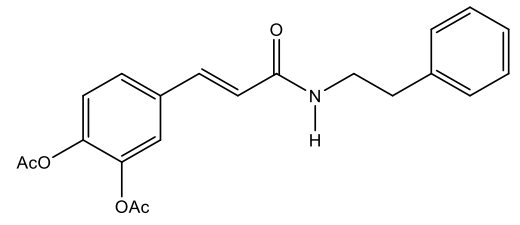

(E)-4-(3-okso-3-(fenetilamino)prop-1-en-1-il)1,2 -fenilen diasetat (3)

Figure 2. Compound produced as a target compound.

Several cytotoxic activities of cinnamic acid derivatives have been tested against murine leukaemia P-388 cells using the MTT method. Therefore, the activity of compound 3 obtained in this study was also determined on the test cells and the method.

\section{Experimental}

\section{Material and Methods}

98\% caffeic acid was purchased from Sigma Aldrich, phenethylamine, acetic anhydride, pyridine, methanol, thionyl chloride, benzene, dichloromethane, triethylamine, pyrrolidine, $\mathrm{HCl}, \mathrm{H} 2 \mathrm{SO} 4, \mathrm{NH} 4 \mathrm{Cl}$, sodium sulfate anhydrous, ethyl acetate, chloroform, n-hexane, TLC plates, whatman 42 filter paper were purchased from Merck, the technical aquadest.

FT-IR Spectrometer (IRPrestige-21), a set of reflux apparatus, evaporator (Buchi), Buchner filter, separating funnel, melting point apparatus (Electrothermal), analytical balance, UV lamps, a set of glassware and supporting organic chemistry laboratories.

\section{The acetylation stage}

1.0 gram $(6.0 \mathrm{mmol})$ of caffeic acid was put into a threeneck round bottom flask, then added $3.0 \mathrm{~mL}$ of pyridine and $1.8 \mathrm{ml}(17.0 \mathrm{mmol})$ of acetic anhydride. The reaction mixture is stirred using a stirrer for \pm 2 hours at room temperature. Next, the reaction mixture was added to 50.0 $\mathrm{ml}$ of cold distilled water while stirring. The formed white precipitate is filtered, washed with distilled water and dried in a desiccator to obtain a dry white solid. The solid is recrystallized from a methanol solvent then filtered to obtain a filtrate, and allowed to stand in the refrigerator until a white crystal is formed. Subsequently, the solids were tested for their melting point and purity through TLC analysis with three kinds of eluent systems. The pure crystals obtained were analyzed by FT-IR spectroscopy. IR $(\mathrm{KBr}):$ o $(\mathrm{cm}-1)=1762.94(\mathrm{C}=0$, acetyl ester $), 1217,08$ \& 1114,86 (C-0, phenolic), 1629,85 (C=C, alkenes), 3057,17 (C-H unsaturated), 1504,48 (C=C, Ar), 1190,08 \& 1016,49 (C-0 ester), 985,62 (trans-olefin), 788,89 \& 690,52 (monosubst. Ar), 2980,02 \& 2821,86 (C-H saturated), 1431,18 \& 1373,32 (CH3).

\section{Chlorination Stage}

The acetylation stage compound of 1.2 grams $(5.0 \mathrm{mmol})$ was dissolved in $15 \mathrm{~mL}$ benzene and added with SOCl2 0.5 $\mathrm{mL}(7.2 \mathrm{mmol})$. The reaction mixture was refluxed for 4 hours, and nitrogen gas drained for 7 minutes. After reflux, the reaction mixture was cooled until room temperature and evaporated until a yellow solid was obtained.

\section{Amidation Stage}

The chlorination stage compound was added with $0.4 \mathrm{~mL}$ ( $4.0 \mathrm{mmol}$ ) of phenethylamine, $0.1 \mathrm{ml}(0.9 \mathrm{mmol})$ of pyridine and $0.4 \mathrm{ml}(2.9 \mathrm{mmol})$ of triethylamine. The mixture was then dissolved in $30.0 \mathrm{ml}$ dichloromethane and sterilized for 1 hour, washed with $\mathrm{HCl}$ then $\mathrm{NH} 4 \mathrm{Cl}$, dried using anhydrous 
$\mathrm{Na} 2 \mathrm{SO} 4$, then evaporated. Furthermore, recrystallization and purity were tested through TLC analysis with three eluent systems and melting point measurements. The pure crystals obtained were further analyzed by FT-IR, 1H-NMR, 13C-NMR, HSQC, and HMBC spectroscopy. IR (KBr): õ (cm$1)=3309.85(\mathrm{NH}$ secondary $), 3062.96 \& 3028.24(\mathrm{C}-\mathrm{H}$ unsaturated), 1656.85 ( $\mathrm{C}=\mathrm{O}$ amide), 1388.60 ( $\mathrm{C}-\mathrm{N}$ amide), 1762.94 ( $\mathrm{C}=0$ ester), $1608.63 \& 1500.62$ ( $\mathrm{C}=\mathrm{C}$ aromatic), $1429.25 \& 1369.46$ (CH3), 975.98 (C-H trans olefin), 748.38
\& 702.09 (subtituted aromatic), $2960.73 \& 2860.43$ (C-H saturated), 1429,25 (CH2), 1369,46 (CH3). 13C-NMR $(\mathrm{CDCl} 3): \mathrm{d}(\mathrm{ppm})=20.6,20.8,35.1,40.6,122.9,123.8,125.9$, 126.4, 127.7, 128.6, 131.2, 139.4, 142.5, 143.2, 165.5, 168.2, dan 168.3. 1H-NMR (CDCl3): d (ppm) $=7.54(1 \mathrm{H}, \mathrm{d}, \mathrm{J}=15.6$ $\mathrm{Hz}, \mathrm{H}-3), 6.23(1 \mathrm{H}, \mathrm{d}, \mathrm{J}=12.6 \mathrm{~Hz}, \mathrm{H}-2), 3.65(2 \mathrm{H}, \mathrm{J}=6.7 \mathrm{~Hz}, \mathrm{H}-$ 14), $2.88(2 \mathrm{H}, \mathrm{J}=6.9 \mathrm{~Hz}, \mathrm{H}-15), 7.17-7.34 ; 2.29$ (3H, s, J=1.45 Hz, H-11), 2.91 (3H, s, J=1.45 Hz, H-13), 5.63 (1H, t, J=5.75 $\mathrm{Hz}, \mathrm{N}-\mathrm{H})$.

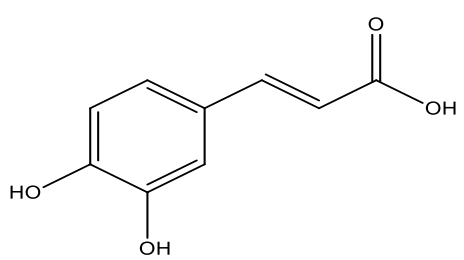

Asam (E)-3-(3,4-dihidroksif enil)akrilat

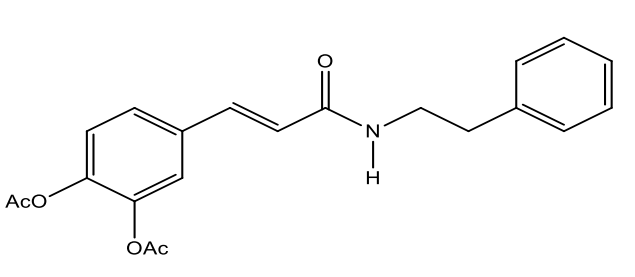

(E)-4-(3-okso-3-(fenetilamino)prop-1-en-1-il)1,2-fenilen diasetat (3)

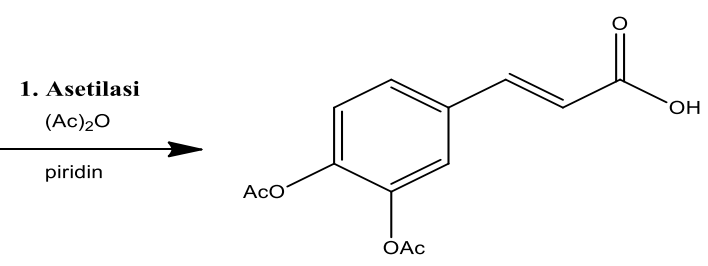

Asam (E)-3-(3,4-diasetoksifenil)akrilik (1)

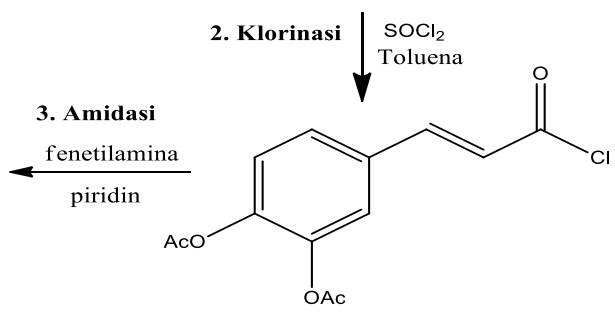

(E)-4-(3-kloro-3-oxoprop-1-en-1-yl)1,2-fenilin diasetat (2)

Figure 3. Schematic synthesis of compound (E)-4-(3-oxo-3-(phenethylamino)prop-1-en-1-yl)-1,2-phenylene diacetate.

\section{Anticancer Bioactivity Test}

Bioactivity test of synthesis compound against murine leukaemia P-388 cells was carried out by the MTT method. The target compound in various concentrations and Artonin-E as a comparison was added to murine leukemia P-388 cells which were then incubated for 48 hours. Subsequently, the sample was added to the colouring reagent ([3-(4,5-dimethyltiazo-2-il)-2,5diphenyltetrazoliumbromide) and re-incubated for 4 hours.

After adding stop solution reagents, sample uptake was measured using a microplate reader at $\lambda=540 \mathrm{~nm}$, then the number of murine leukemia P-388 cells that were inhibited by the sample was calculated to obtain an IC50 value

\section{Result and Discussion}

Each product in the synthesis stages was tested using an FT-IR spectrometer, except for chlorination product that was not purified. Specifically for compound 3, the characterization was continued by using ${ }^{1} \mathrm{H}-\mathrm{NMR}$ spectrometers, ${ }^{13} \mathrm{C}-\mathrm{NMR}$, HSQC, and HMBC.

\section{Synthesis of compound 1}

At this stage, a white crystalline product with a melting point of $182-184 \mathrm{oC}$ and a yield of $77 \%$ was obtained. The comparison of FT-IR spectra of (E)-3-(3,4dihydroxyphenyl) acrylate acid precursor compound (Figure 1) and acrylic (E)3-(3,4-diethoxyphenyl) acid (compound 1) showed the success of the acetylation reaction.

The FT-IR spectrum of compound 1 shows the presence of a typical carbonyl $(\mathrm{C}=0)$ ester group with a sharp absorption band and strong intensity at wave number of $1762.94 \mathrm{~cm}-1$ and supported by the presence of C-O acetyl ester bonds in the region of $1190.08 \mathrm{~cm}-1$ and 1016, $49 \mathrm{~cm}$ 1. The absence of $\mathrm{OH}$ phenolic absorption band at 3437.15 $\mathrm{cm}-1$ is a sign that the compound has undergone an acetylation reaction, both in the phenolic group and in the carboxylic group. FTIR spectra data of precursor compounds and compound 1 are summarized in Table 1.

\section{Synthesis of compound 2}

The product of the synthesis reaction of compound 2 was 
used without further purification because it is thought to be very reactive to water, even with water vapour in the air can cause $\mathrm{Cl}$ to be substituted with $\mathrm{OH}$ again. Therefore, the yellow solid obtained in this reaction stage was continued to the amortization stage in situ.

Table 1. FT-IR spectrum data and groups in compound 1

\begin{tabular}{lcc}
\hline \multicolumn{1}{c}{ Functional } & \multicolumn{2}{c}{ Wave Number $\left(\mathbf{c m}^{-1}\right)$} \\
\cline { 2 - 3 } & Caffeic acid & $\begin{array}{c}\text { Synthesis } \\
\text { Results 1 }\end{array}$ \\
\hline O-H phenolic & 3437,15 & - \\
O-H carboxylate & 3435,22 & - \\
C=O carboksil & 1645,28 & - \\
C=O ester & - & 1762,94 \\
C-O phenolic & $1217,08 \& 1116,78$ & $1217,08 \&$ \\
& & 1114,86 \\
C-O carboksil & 1172,72 & - \\
C-O ester & - & $1190,08 \&$ \\
& & 1016,49 \\
C-H unsaterated & 3053,32 & 3057,17 \\
C=C alkenes & 1664,57 & 1629,85 \\
C=C aromatic & $1597,06 \&$ & $1579,70 \&$ \\
& 1514,12 & 1504,48 \\
trans-olefin & 968,27 & 985,62 \\
Mono-subts. Ar. & $734,88 \& 698,23$ & $788,89 \& 690,52$ \\
C-H alkanes & $2985,81 \&$ & $2980,02 \&$ \\
& 2829,57 & 2821,86 \\
CH ${ }_{3}$ & - & $1431,18 \&$ \\
& & 1373,32 \\
\hline
\end{tabular}

\section{Synthesis of compounds 3}

At this stage, a white crystalline product with a melting point of $170-1730 \mathrm{o}$ obtained. In the FT-IR spectrum, there is a sharp absorption band with moderate intensity at $3309.85 \mathrm{~cm}-1$ which is an amide II absorption band $(\mathrm{N}-\mathrm{H}$ strain) which is supported by absorption band at 1544.98 $\mathrm{cm}-1$ (N-H bend). The amide I absorption band $(\mathrm{C}=\mathrm{O})$ appears at $1656.85 \mathrm{~cm}-1$, and the amide III absorption band appears at $1309.67 \mathrm{~cm}-1$. Another absorption band showing the presence of a carbonyl group $(\mathrm{C}=0)$ ester appears at wave number of $1762.94 \mathrm{~cm}-1$. The absorption bands at 3062.96 and $3028.24 \mathrm{~cm}-1$ indicate the presence of unsaturated $\mathrm{C}-\mathrm{H}$ groups. The presence of aromatic groups is indicated by absorption bands at 1608.63 and $1500.62 \mathrm{~cm}-1$. The absorption bands at 748.38 and 702.09 $\mathrm{cm}-1$ represent mono-aromatic substitution, and this is in accordance with the presence of a penetrating group. The saturated $\mathrm{C}-\mathrm{H}$ group is shown by absorption bands at 2960.73 and $2860.43 \mathrm{~cm}-1$. The presence of methyl groups is shown by absorption bands at 1452.40 and $1369.46 \mathrm{~cm}$ 1. Spectrum absorption bands of compound 1 and compound 3 and their relation to the groups contained in each are presented in Table 2.
Table 2. FT-IR spectrum data and groups in compound 3.

\begin{tabular}{|c|c|c|}
\hline \multirow[b]{2}{*}{$\begin{array}{c}\text { Functional } \\
\text { Groups }\end{array}$} & \multicolumn{2}{|c|}{ Wave Number $\left(\mathrm{cm}^{-1}\right)$} \\
\hline & $\begin{array}{l}\text { The results of } \\
\text { the synthetis of } \\
\text { compound } 3\end{array}$ & Compound 1 \\
\hline N-H secondary & 3309,85 & - \\
\hline $\mathrm{C}-\mathrm{H}$ alkenes & $\begin{array}{c}3062,96 \& \\
3028,24\end{array}$ & 3057,17 \\
\hline C-H saturated & $\begin{array}{c}2960,73 \& \\
2860,43\end{array}$ & $\begin{array}{c}2980,02 \& \\
2821,86\end{array}$ \\
\hline $\mathrm{C}=\mathrm{O}$ amide & 1656,85 & - \\
\hline C-N amide & 1388.60 & - \\
\hline $\mathrm{C}=\mathrm{O}$ ester & 1762,94 & 1762,94 \\
\hline $\mathrm{C}=\mathrm{C}$ aromatic & $\begin{array}{c}1608,63 \& \\
1500,62\end{array}$ & 1504,48 \\
\hline $\mathrm{CH}_{3}$ & $\begin{array}{c}1429,25 \& \\
1369,46\end{array}$ & $\begin{array}{c}1431,18 \& \\
1373,32\end{array}$ \\
\hline $\mathrm{C}-\mathrm{H}$ trans olefin & 975,98 & 985,62 \\
\hline $\begin{array}{l}\text { Subtituted } \\
\text { aromatics }\end{array}$ & $748,38 \& 702.09$ & $\begin{array}{c}725.23 \& \\
690,52\end{array}$ \\
\hline
\end{tabular}

The ${ }^{13} \mathrm{C}-\mathrm{NMR}$ spectrum of compound 3 (Figure 4) shows that there are 19 signals representing $21 \mathrm{C}$ atoms because there are two signals representing the positions of carbon atoms that are identical in their chemical environment, namely C-17 and C-21 and C-18 and C-20.

Signals that appear in the highest shift region, namely at d $168.3 \mathrm{ppm}, 168.2 \mathrm{ppm}$, and $165.5 \mathrm{ppm}$ each come from two groups of $\mathrm{C}=\mathrm{O}$ carbonyl phenolic esters of acetate ( $\mathrm{C}$ 10 and $\mathrm{C}-12$ ) and $\mathrm{C}=0$ amide group ( $\mathrm{C}-1)$.

The six atoms of $C$ in the benzene caffeoil group give signals on successive chemical shifts: d 126.4; 123.8; 143.2; 142,5; 122.9; and 131.2 ppm (C-9, C-8, C-7, C-6, C-5, and $\mathrm{C}-4)$. The benzene ring of the phenethyl group gives four C signals namely: d 139.4 (C-16); 127.7 (C-17, and C21); 128.6 (C-18 and C-20); and 125.9 (C-19) ppm. The chemical shift of the $\mathrm{C}$-sp3 atom includes two $\mathrm{C}$ methylene groups at d $40.6 \mathrm{ppm}(\mathrm{C}-14)$ and d $35.1 \mathrm{ppm}$ (C-15), and two methyl groups at 20.8 and 20.6 ppm respectively.

The ${ }^{1} \mathrm{H}-\mathrm{NMR}$ spectrum of compound 3 (Figure 5) indicates the existence of a spin olefin system with trans conformation at $\mathrm{d} 7.54 \mathrm{ppm}(1 \mathrm{H}, \mathrm{d}, \mathrm{J}=15.6 \mathrm{~Hz}, \mathrm{H}-3)$ and $6.23 \mathrm{ppm}(1 \mathrm{H}, \mathrm{d}, \mathrm{J}=12.6 \mathrm{~Hz}, \mathrm{H}-2)$. Two types of methyl protons in the phenethyl group each appear as tetraplets at d $3.65 \mathrm{ppm}$ and triplets at d 2.88. Three aromatic protons of the phenolic group and five protons of the phenyl group all give signals that appear in the region of $d$ $7.17-7.34$ ppm, while the methyl protons of the two acetyl groups appear as two singlet signals at d 2,293 and 2.91 ppm with integration values each of 3 (total of 6). The proton group (-CO) N-H (amide) appears at d $5.63 \mathrm{ppm}$. 
in Table 3.

Table 3. Correlation of HMBC and HSQC Compounds 3

\begin{tabular}{lll}
\hline \multicolumn{1}{c}{ H } & \multicolumn{1}{c}{ C HSQC } & \multicolumn{1}{c}{ C HMBC } \\
\hline H-2 & C-2 & C-4, C-1 \\
H-11 \& H-13 & C-11 \& C-13 & C-10, C-12 \\
H-17 \& H-21 & H-17 \& H-21 & C-19; C-16, \\
H-3 & C-3 & C-5, C-8, \& C-6 \\
H-5 & C-5 & C-9, C-4, \& C-6 \\
H-9 & C-9 & C-5, C-8, C-1 \\
H-14 & C-14 & C-15, C-1, C-16 \\
H-15 & C-15 & C-14, C-16, C-18, \\
& & C-17, C-20, C-21 \\
H-19 & C-19 & C-6, C-18, C-20, \\
& & C-17, C-21, C-15 \\
\hline
\end{tabular}

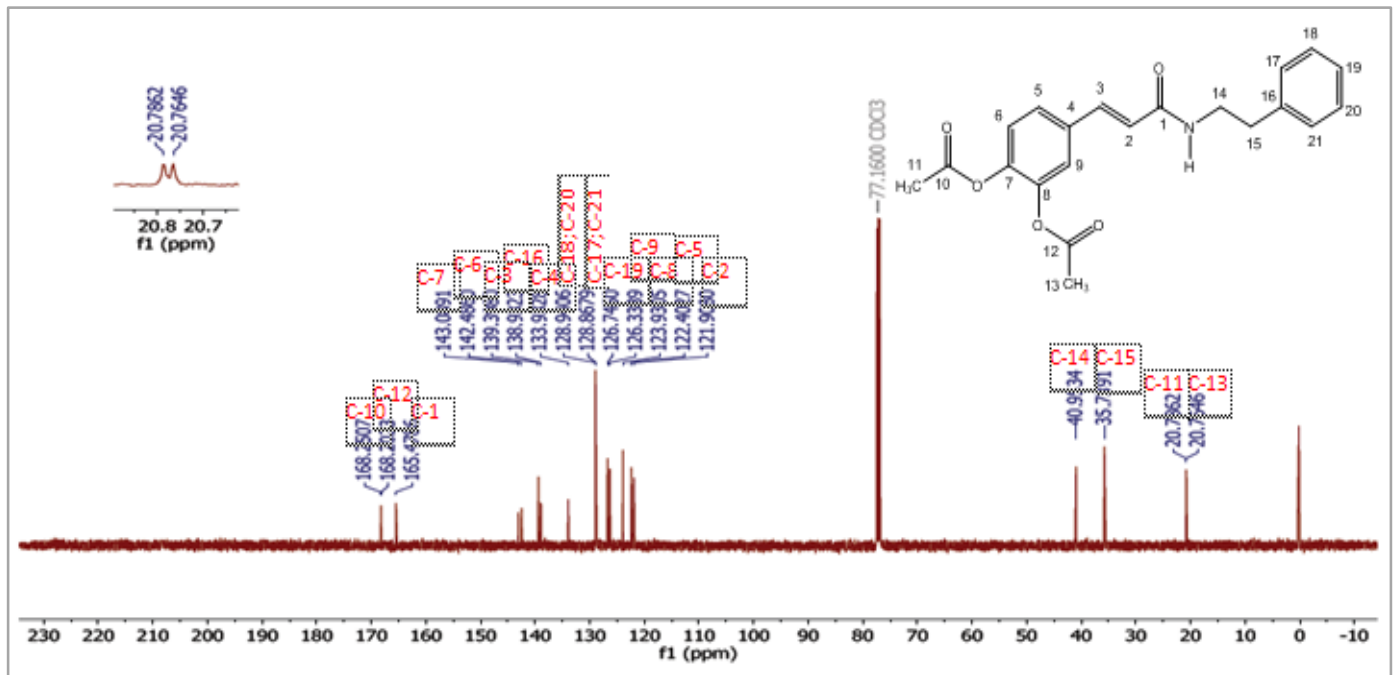

Figure 4. ${ }^{13} \mathrm{C}-\mathrm{NMR}$ spectrum of compound (E)-4-(3-oxo-3-(phenethylamino)prop-1-en-1-yl)-1,2-phenylene diacetate (compound 3).

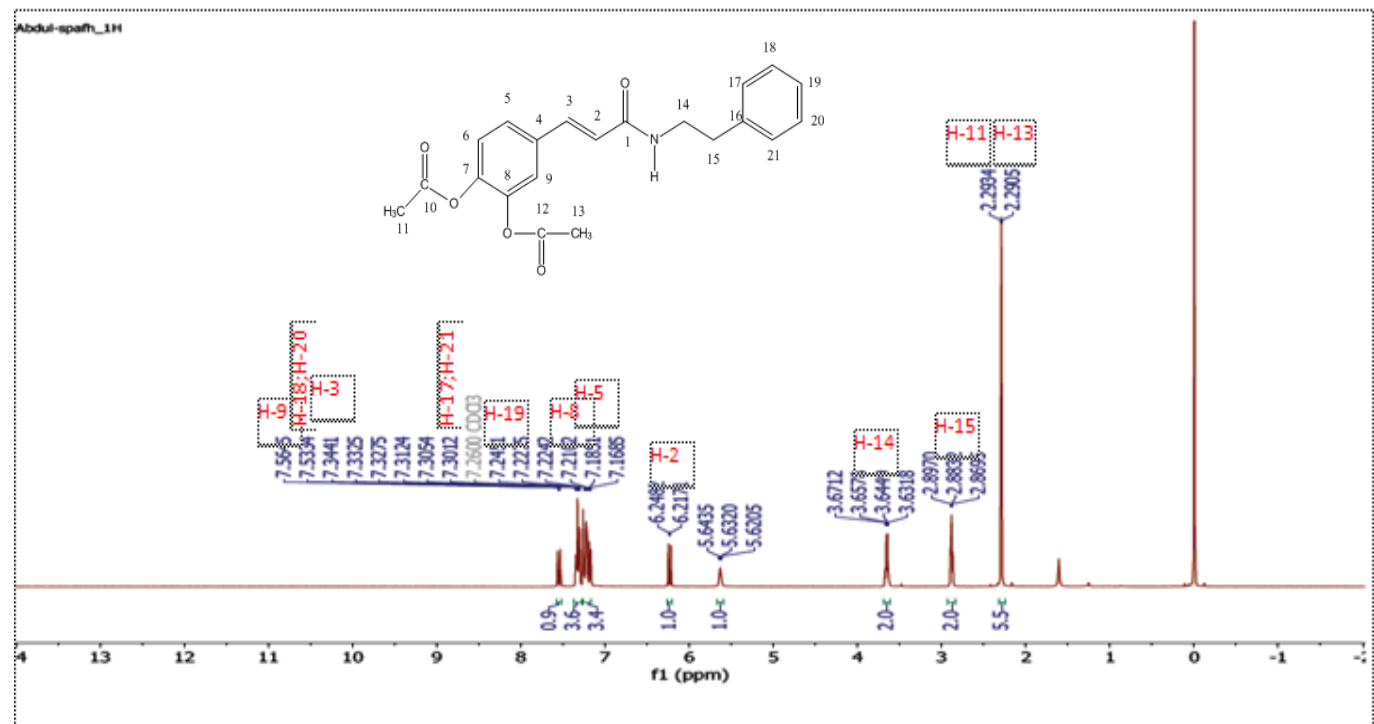

Figure 5. ${ }^{1} \mathrm{H}-\mathrm{NMR}$ spectrum of compound (E)-4-(3-oxo-3-(phenethylamino)prop-1-en-1-yl)-1,2-phenylene diacetate. 


\section{Bioactivity Assay Against P-388 Leukemia Cells}

Bioactivity study of compound 3 against P-388 leukemia cells resulted IC50 of $0.5 \mu \mathrm{g} / \mathrm{mL}$. The categories in cytotoxic compounds according to the US National Cancer Institute consist of 4 categories, namely very toxic categories if IC50 values $\leq 20 \mu \mathrm{g} / \mathrm{mL}$, moderate or sufficient cytotoxics active if the IC50 value is in the range of $21-200 \mu \mathrm{g} / \mathrm{mL}$, cytotoxic is weak if the IC50 value is in the range $201-500 \mu \mathrm{g} / \mathrm{mL}$ and if the IC50 value $\geq 500 \mu \mathrm{g} / \mathrm{mL}$, it is included in the non-toxic category (Abdel-Hameed et al., 2012 ). In other words, the smaller the IC50 value produced by a compound, the greater the cytotoxic activity.

Based on the above categories, the results of the bioactivity test of compound 3 are categorized as very toxic to P-388 leukaemia cells, because the IC50 value is $\leq 20$ $\mu \mathrm{g} / \mathrm{ml}$.

The intense activity of compound 3 is thought to be related to the low polarity of the compound, which makes it possible to penetrate cell walls easily and provide inhibition of leukaemia cell growth. This is different from caffeic acid, which has a higher polarity, so it is difficult to penetrate the cell wall and cause the smaller concentration of caffeic acid to be adsorbed by cells.

In the conversion of hydroxyl groups, caffeic acid into ester groups and the conversion of carboxylic acid groups to amides resulted in a decrease in polarity of the compound and its stability also increased, thus allowing the bioactivity of compounds to increase. This is reflected by the IC50 value of compound 3 against murine leukaemia P388 cells of $0.5 \mu \mathrm{g} / \mathrm{mL}$, while caffeic acid gives an IC50 of $54.31 \mu \mathrm{g} / \mathrm{mL}$ (Son, 2002)

Comparing the results of previous studies on the bioactivity of amide analogue compounds against murine leukaemia P-388 cells, namely phenethyl trans-3-(4hydroxy-3-methoxyphenyl)acrylate with IC50 of 10.79 $\mu \mathrm{g} / \mathrm{mL}$ and trans-3-(4-hydroxy-3-methoxyphenyl)-Nphenethylacrylamide with IC50 of $29.14 \mu \mathrm{g} / \mathrm{mL}$ (Firdaus et al., 2016), the activity of compound 3 is higher than the two compounds.

This fact shows that in addition to the p-hydroxycinamide group, amide groups also affect the bioactivity of cinnamic acid derivative.

\section{Conclusion}

Synthesis of compound (E) -4- (3-oxo-3(phenethylamine) prop-1-en-1-il) -1,2-phenyl diacetate from caffeic acid has been successfully carried out. Bioactivity test for murine leukaemia P-338 cells gave IC50 value of $0.5 \mu \mathrm{g} / \mathrm{mL}$. This compound is more active than caffeic acid compounds as precursors and analogue compounds synthesized in previous studies.

\section{References}

Abdel-Hameed E.-S.S., Bazaid S.A., Shohayeb M.M., El-Sayed M.M. dan El-Walkil E.A., 2012, Phytochemical Studies and Evaluation of Antioxidant, Anticancer and Antimicrobial Properties of Conocarpus erectus L. Growing in Taif, Saudi Arabia, Eur. J. of Medicinal Plants, 2 (2), 93-112.

Firdaus, Soekamto, N. H., Permatasari, N. U., Seniwati, Sukarti, dan Makmun. 2012. Synthesis of Secondary and Tertiary Derivatives of p-Kumaramide and Its Activity Test as Antitumor P-388 Leukemia Cells. Indonesia Chimica Acta. 5 (2): 10-16.

Firdaus, N H Soekamto, Seniwati, M F Islam dan Sultan. 2016. Phenethyl ester and amide of Ferulic Acids: Synthesis and bioactivity against P-388 Leukemia Murine Cells. J. Phys.: Conf. Ser. 979012016

Cho, M. S., 2014. Caffeic acid phenethyl ester promotes antiinflammatory effects by inhibiting MAPK and NF$\kappa \mathrm{B}$ signaling in activated HMC-1 human mast cells. Pharm Biol, 2014; 52(7): 926-932

Hung, C.C., Tsai, W.J., , Kuo, L.M.Y., and Kuo, Y.H. 2005. Evaluation of Caffeic Acid Amide Analogues as Antiplatelet Aggregation and Anti-oxidative Agents. Bioorganic \& Medicinal Chemistry. 13: 1791-1797 Nakamura, K., Nakajima, T., Aoyama, T., dan Okitsu, S., 2014, One-pot Esterification and Amidation of Phenolic Acids, Tetrahedron, 30: 1-11.

Nakamura, K. 2014. One-pot esterification and amidation of phenolic acids. Tetrahedron, $1-11$

Peng, W., Wu, J.G., Jian, Y.B., Liu, Y.J., Sun, T., et al. 2015. Antitumor Activity of 4-0-(2"-0-acetyl-6"-0-pcoumaroyl- $\beta$-D-glucopyranosyl)-p-coumaric Acid Against Lung Cancers Via Mitochondrial-mediated Apoptosis, Chemico-Biological Interactions. 233: 8-13.

Pranowo, H.D., 2003, Computational Chemistry, Center for Computational Chemistry Indonesia-Austria Kimia, FMIPA UGM, Yogyakarta

Rajan, P., Vedernikova, I., Cos, P., Berghe, D. V., Augustynsa, K., dan Haemers, K., 2001, Synthesis and Evaluation of Caffeic Acid Amides as Antioxidants, Bioorg. Med. Chem. Lett., 11: 215-217.

Sharma, P. 2011. Cinnamic acid derivatives: A new chapter of various pharmacological activities. Journal of Chemical and Pharmaceutical Research. 3 (2): 403423.

Simon-Hettich, Rothfuss, A., Thomas, S., H., 2006, Use of Computer-assisted Prediction of Toxic Efffects of Chemical Substances, Toxicology 224, 154-162.

Stankova, I. and Spasova, M. 2009. Hydroxycinnamic Acid Amides with Oxazole-Containing Amino Acid: Synthesis and Antioxidant Activity. Z. Naturforsch. 64 (c): 176-178.

Tropsha, A., Golbraikh, A., 2007, Predictive QSAR Modelling Workflow, Model Applicability Domains, and Virtual Screening. Current Pharmaceutical Design, 13, 34943504 
Zhang, P., Yuping Tang, Nian-Guang Li, Yue Zhu, and Jin-Ao Duan. 2014. Bioactivity and Chemical Synthesis of
Caffeic Acid Phenethy Ester and Its Derivatives. Molecules. 19: 16458-16476. 